\title{
ep 系マウスの凐摹阻止に関する実験的研究
}

\author{
第 1 編 \\ 各種抗痙擎剂の ep 系マウス痙攣発作に及ぼす影響について \\ （本諭文の要旨は第 10 回日本生化学会中国四国部会総会において発表した。） \\ 岡山大学医学部第 1 (陳内) 外科教室 (指導 : 阵内教授) \\ 学学管原閏治
}

[昭和 37 年 7 月 30 日受槁]

\section{第1 章 緒言ならびに文献}

私どあの教室では数年前より，てんかんの原因を 究明するため，てんかん素質あるいは座慗準備状態 の研究を志し，手術の際元られたてんかん忠者脳の 焦点組織を用い，さらにてれと平行して稀薄な抗原 を用いて実験的に作成した潜在性脳局所アナフィラ キシー動物の敛の組織について，今日まで極めて数 多くの生化学的研觉がおてなわれてきており，てれ らの結果は陳内の綜搃122334) に報告されている。一 方，1954年今泉5)に上つて発見された ep 系マウス は，座慗準備状態の異常穴進が遗伝的に規定されて いて，他動的な体位変顿刺激によつて，成熟マウス では100\%に应㘘発作を起すととができるという点 で, 氫繁準借状態，ひいてはてんかん性痙變発作の 発現機序を解明するに極好都合な実験動物であ る.したがつて現在私どあの教室もこの特殊な純系 マウスに着目し，その生化学的ならびに生理学的研 觉を進めているわけである.

さて氫㢣発作の発現機序を解明せんがためには，

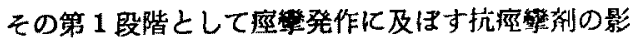
整を検索するととが必要不可欠なととと考えて，私 は ep 系マウスを用いて本編の研究を企てた次箱で ある.

従来とのマウス脳の物質代謝(とくに acetylcholine 代謝， $\mathrm{NH}_{3}$ および glutamine 酸系アミノ酸代謝等) に関する若干の生化学的特性はすでに成瀬ら67)に

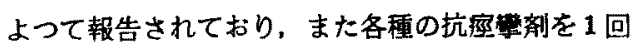
急性負荷した際の ep 系マウスの氫算発作に及ばす 影響についても，すでに矢部㫙により報告されてい るが，しかしながら，抗座學剂の効果はその用量や
投与期閒の長短等によりかなり異なるものであつて， したがつて私はまず各種の抗座剂のうち，従来より 座数之の関係が重要視され、互いに代謝的比関連し て中枢神経抑制作用および抗症綵作用について注目 されてきた遊離了ミノ酸，すなわち L-gluts.mic acid, L-asparagine, $\gamma$-aminobutyric acid (以下GABA と略す)，およびそ-amino. $\beta$-hydroxybutyric acid (以 下 GABOB と略す) を選び，さらに Merritt およ び Putnanによつて 1938 年米国に书いて㓣製さ

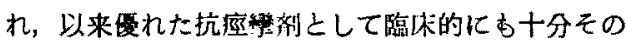
評価加確誌されている diphenylhydantoin（以下 Dph. と略す）を取り上げ、これらの各䔉剂の十分 広篍囲にわたる程々の用量を ep 系マウスに長期間 連絸投与して，その際における ep 系マウスの痙揫 発作に及ほす抑制効果の有無を検索してみるととと した.

\section{第2章 実臨方法}

\section{第 1 節 実験動物}

生後 15 週以上経過した体重 $25 \sim 30 \mathrm{~g}$ 前後の $\mathrm{ep}$ 系マウスを用いた，ep 系マウスは予防衛生研究所 の今泉㗊疫部長により分与されたもので，特殊慗殖

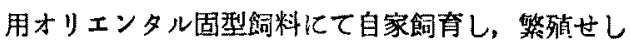
めて何代かを経過した純系マウスである，ep 系、 ウスは一定の他動的な体位变换刺激を絽返して与え るとおそくとも生後 11 週以上経過したものでは定 型的な座繁発作を起すようになる，乙の発作型式に ついては今泉ららうおよび矢部8にによ詳しく報告さ れている。

私は ep 系マウスの発作誘発に必要な他動的な体 位恋換刺湤として， ep 系マウスを平板上に路き， 
約 $20 \sim 30 \mathrm{~cm}$ 位柽く振り上げる操作を繰返す今泉 の原法に従い，との操作を少なくとす40回繰返す

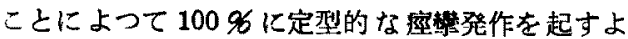

うに訓練したマウスをすへて用いるとととした。

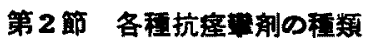

私の実験に使用した整剂の種類は次に揭げる通り である。

1) Glutamic acid 和北純落

2) Asparagine 和北純菲

3） GABA 第一製悲（ガンマロン）

4） GABOB 小野製菜（ガミベタール）

5）Dph. 大日本製薬（アレビアチン）

彆のものを使用した。

第3 節抗痤剂の投与法

Glutamic acid, asparagine, GABA，および GABOB は水溶性であるのて，溶媒は蒸溜水とし， 注射液量を $0.2 \sim 0.5 \mathrm{ml}$ として腹腔内に注射した。

Dph.はアルカリ性にしないと溶解しないし，アル

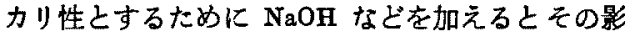

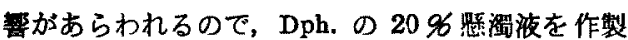
して，その $0.2 \sim 0.5 \mathrm{ml}$ を投与液量として経口投 与することにした，すなわち $1 \mathrm{ml}$ 用の注射筒の先 を約 $3 \mathrm{~cm}$ 延ばし尖端を細くしたすのを手製し，マ ウスを左手で軽くつかみ，乙の注射筒を口中にでき るだけ深く入れて，その尖端が喉頭を過ぎて食道に まで達するようにし，呼吸をみながら静かに右手の 親指で注射筒を押してやる. かくしててれらの薬剂 の下記用量を ep 系マウスに1日1回 3 週連続投与 した.

1) Glutamic acid 100 1000 mg/kg の各 $100 \mathrm{mg} / \mathrm{kg}$ 間隔每

2) Asparagine $100 \sim 1000 \mathrm{mg} / \mathrm{kg} の$ 各 $100 \mathrm{mg} / \mathrm{kg}$ 間隔許

3) GABA 100 1000 mg/kg の各 $100 \mathrm{mg} / \mathrm{kg}$ 間隔每および $1000 〜 2000 \mathrm{mg} / \mathrm{kg}$ の各 $200 \mathrm{mg} / \mathrm{kg}$ 間隔毎

4) GABOB 200 1200 mg/kg の各 $200 \mathrm{mg} / \mathrm{kg}$ 間隔每

5) $D_{\mathrm{ph} .} \quad 40 \sim 60 \mathrm{mg} / \mathrm{kg}$ の各 $10 \mathrm{mg} / \mathrm{kg}$ 間㣂 毎および 60 100 mg/kg の各 20 $\mathrm{mg} / \mathrm{kg}$ 間隔毎

第 4 節 痤動発作の判定法

上記抗应變剂の投与後，一律䎲 1 時間目，4 洔間 目， 8 時間目， 12 洔間目，および 24 時間目に，そ れぞれ第 2 章，第 1 節においてのべたごとき体位変
換刺激を ep 系マウスに与え, 100 回の刺激を加え ても発作の起らない場合には 1 ～2 分の休止期間を おき，さらに40回の刺激を与えて应變発作の有笎 を判定した。

\section{第3 章 実験成縝}

第 2 章，第 3 節においてのぺたでとき投与法によ $り$, ep 系マウスに glutamic acid, asparagine, GABA，GABOB および Dph.を投与し，ep 系 マ

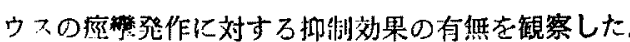
その成縜は第 1 表のごとくである. 第 2 章, 第 4 節 においてのべたごとき判定方法により発作を起した おのを無効とし，発作の消失したすのを有効とし た.

第1表 ep 系マウス空學発作代対する各種抗

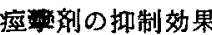

\begin{tabular}{|c|c|c|c|}
\hline 類 & 投 与 量 & 例数 & 判 定 \\
\hline L-glutamic acid & $\int_{1000 \mathrm{mg} / \mathrm{kg}}^{100 \mathrm{mg} / \mathrm{kg}}$ & |各5例 $\mid$ & 無 効 \\
\hline L-asparagine & $\begin{array}{l}\int_{1000 \mathrm{mg} / \mathrm{kg}}^{100 \mathrm{mg} / \mathrm{kg}} \\
\int_{0} 100 \mathrm{mg} / \mathrm{kg} \text { 每 }\end{array}$ & 各5例 & 無 \\
\hline \multirow{2}{*}{ GABA } & $\begin{array}{l}\int_{1000 \mathrm{mg} / \mathrm{kg}}^{100 \mathrm{mg} / \mathrm{kg}} \\
\int_{0} 100 \mathrm{mg} / \mathrm{kg} \text { 每 }\end{array}$ & \multirow{2}{*}{ 各5例 } & \multirow{2}{*}{ 無 } \\
\hline & $\int_{2000 \mathrm{mg} / \mathrm{kg}}^{1200 \mathrm{mg} / \mathrm{kg}}$ & & \\
\hline GABOB & $\begin{array}{l}200 \mathrm{mg} / \mathrm{kg} \\
\int_{1200 \mathrm{mg} / \mathrm{kg}} 200 \mathrm{mg} / \mathrm{kg} \text { 毎 }\end{array}$ & |夂口各5例 $\mid$ & 無 \\
\hline \multirow{3}{*}{$\begin{array}{l}\text { Diphengl- } \\
\text { hydantoin }\end{array}$} & $\mathrm{A} \mid \int_{60 \mathrm{mg} / \mathrm{kg}}^{40 \mathrm{mg} / \mathrm{kg}}$ & \multirow{3}{*}{ 各5例 } & 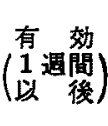 \\
\hline & $80 \mathrm{mg} / \mathrm{kg}$ & & 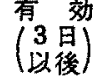 \\
\hline & $100 \mathrm{mg} / \mathrm{kg}$ & & 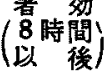 \\
\hline
\end{tabular}

1) Glutamic acid, asparagine, GABA, および GABOB の投与の場合

第 1 表に示したごとき笔围内の用量では各例とも すべて 3 週間の全経過を通じて体位变換刺激により 痤繁作加発現し，全く抑制効果は認めら扎なか 
た．またとれらの萝剂の投与期間中なんら全身的変 化は認められなかつた。

2) Dph. 投与の場合

Aに示す投与量では初めの1 週間のみ，Bに示す 投与量では初めの 3 日間のみ，発作がみられ，以 後 ep 系マウスの㮒杽発作は全く認みられなくなつ

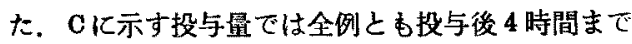

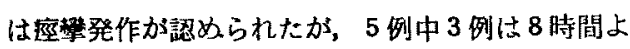
り座繁発作は消失し，残りの 2 例は 8 時間目軙度の 発作徵候を示したのみで，以後 $\mathrm{ep}$ 系マウスの应繁 発作は全く認められなくなつた。

Dph.の投与を 3 週間連続投与したのち中止する と, ep 系マウスは全例とも括をくとも6 日以後よ り再び初めは不全型, 次いで定型的な座督発作を示 してきた.

\section{第4章 総括ならびに考按}

今日まで glutamic acid のほか, 種々のアミノ酸 を動物に投与しても， blood-brain barrier にさえき られて脳にはほとんど移行しないととが知られてお り9), Wealsch10) む彼の実験の中で glutamic acid は腷の中へはいらないように思われるとのべ, GABAについてもVan Gelder ら11)は脳に移行し ないととを観察し、また教室の森ら12)，および宇

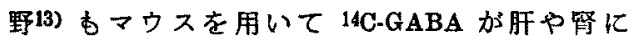
は incorporateされるにもか加わらず，脳には極め て少量しか移行しないととを認めている. 一方 GABOB についても教室の川上14) がウサギに 100 $\mathrm{mg}$ 静注してす脳に移行しないととをみている.し かしこれらの実験估正常な動物にただ 1 回のみ投与 した場合であるが，Tower15) は脳の興峟状態におい ては blood-brain barrier の透過性は增し, 正常以 上に GABA を通過せしめると報告している。した がつて座繁準珄が異常に萑している ep 系 マウスに glutamic acid, asparagine, GABA, およ びGABOB を大量に，しかも長期間連続投与した場 合, これらのアミノ酸は正常マウスにおけるよりも 容易に blood-brain barrier 通過し，あるあのは ep 系マウスの座撃発作を阻止するのではないかと考え られるが、私の実験結果は予期に反して，てれらは いずれも ep 系マウスの应笔作汶対して全く抑制 効果は認められなかつた。 また一方教室の西本, 沼 本，森16）は開頭手術時明膫なる焦点を認みたてん かん患者の焦点皮質の表面に GABA および GABOB を綿に浸して貼布したとてろ1〜2 分後には, 貼布
前化認められた䨩気刺激による after-discharge が 全く消失したととを確認しまた GABA，GABOB の䯣腔内注入が直ちに鲝繁作を消退せしめるとと が実験的にも，隐休的にも知られており17)，てれら

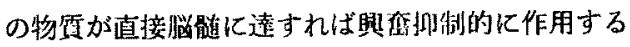
ことは明らかである.これらのととよりかかるアミ ノ酸は ep 系マウス胹においても，blood-brain barrier 通過し嚾く，上記箋囲の投与量にてる ep 系マウスの座繁発作を阻止するだけの脳内濃度 に達しえないすのと考えられる。

次に，一般に芳香族（環状）化合物は脂溶性傾向 を示すので, blood-brain barrier の透過性を容易にし， したがつて水溶性あるいはイオン保有の化合物に比 し比较的讯速に脳に移行寸るあのと考えられている。 この点 Dph. は第 1 図のごとき構造式を有する環状

第 1 脑 Chemical structure of diphenylhydantoin<smiles>O=C1NC(=O)C(c2ccccc2)(c2ccccc2)N1</smiles>

化合物であり，上記の上うな性質を有するすのと考 えられる。事実 Noach ら18)はラッテに 4-14C-labelled diphenylhydantoin を静注し，脳，肝，觜等えの移 行を経時的に追求しているが，脳汅おいて古投与後 急速に高い濃度が検出され，投与後 30 分および 90 分に peak を示すてとを明らかにし，以後すへての 䑏器において濃度は濑次低下し，16〜24 時間の間 に0に達すると報告している。ささに投与された 4-14C-diphenylhydantoin $の$ radioactivity は48時間 以内に $93.7 \%$ 尿中に検出されるが，24時間では僅 加 50 名のみか尿中に排泄され，残りは腸管内に 存在するととを見出し，Dph.は胙により大部分が 5-(p-hydroxyphenyl)-5-phenylhydantoin となり, 胆汁より腸管内に迅速に排泄され，次の緊排泄のた めに再吸収されることを明らかにしている，また Dill ら19) はラッテに $100 \mathrm{mg} / \mathrm{kg} の \mathrm{Dph}$. を経口投 与し, 脳および他の䑏器えの移行を経時的に追求し, D ph. は投与後腸管上り徐々に吸収され，6〜8時 
間目に最も高い濃度で肺および脂肪に，ついで脳に 見出され，とのととは Dph. が blood-brain barrier を容易に通過するととを示すあのであるとのへてい る. Hine ら20）家鬼を用いて，Dph.の大量を7日 間連続経口投与し，释時的に各種䑏器内の分布を調 べ, Dph.はとくに脳において蓄積されることを明ら かにしている. Dill ら21) および Greengard ら2223) は Dph.が一度 blood-brain barrier を通過して脳 内に移行した場合 Dph. は特定の檤領野に対して選 択的浱度を示すことなく，脸の各領野に比較的一定 の分布状態をとり，したがつて Dph.は発作原発

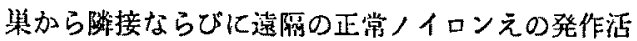
動の伝導および全身移行を最少限にくいとめるに最 あ臨床的に有效な桼剂であり, 主として正常ノイロ ンに対して保護的に働きかけるが，発作原発然伅は 比較的無効なのであろうと述へている.

さて私の実験において, ep 系マウスに Dph.の 各用量を経口投与した場合, ある洔期を境として症 整発作がみられなくなつたというととは，Dph.は blood-brain barrier 客易に通過して脳に移行し,

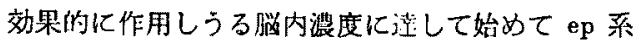
マウスの受攀発作を抑制するもの之考えられる。こ の点 D ph.の ep 系マゥス譄内分布化ついては个後 さらに㭘索を要する問題であると考えられる.

\section{参考文献}

1) 陣内：アレルキーー, 3, 209, 1954.

2) Jinnai, D.: Acta Medicinae Okayama, 8, 423, 1954.

3）陳内，森：神経研究の進步，4，531，1960.

4) Jinnai, D. and Mori, A. Acta Medicinae Okayama, 14, 116, 1960.

5）今泉他：実験動物，8，6，1959.

6) Naruse, H. et al. J. Neurochem., 5, 359, 1960.

7) 秋元，成濑他：神経研究の進歩，4，548，1960.

8）矢部：精神神経学雑誌，61，1683，1959.

9) Friedberg, F. \& Greenberg, D. M. : J. Biol. Chem., 168, 411, 1947.

10) Wealsch, H.: Lancet, 11, 1, 1949.

11) Van Gelder, N. M. \& Elliott, K. A.C.: J. Neurochem., 3, 139, 1958.

12) Mori, A. \& Kosaka, M. , Folia Psychiatf. et

\section{第5章結論}

ep系マウスに glutamic acid, asparagine, GABA, GABOB および diphenylhydantoin の広簌囲にわ たる稿々なる用量を 1 日 1 回 3 週間連続投与し，ep 系マウスの座学発作に及ほ影響を検討し，つぎの ような綕諭をえた。

1) Glutamic acid, asparagine, GABA および GABOB は, ep 系マウスの痤彎発作代対してなん らの抑制効果を認めない.

2) Diphenylhydantoin は ep 系マウスの疷緇発 作に対して有効であり，40 -60 $\mathrm{mg} / \mathrm{kg}$ の投与では おこらくとも 1 週閏以後, $80 \mathrm{mg} / \mathrm{kg}$ 投与ではお己 くとも 3 日以後， $100 \mathrm{mg} / \mathrm{kg}$ の投与ではおそくと 68時間以後に ep 系マウスの庭變発作を全く阻 止宁名.

3) Diphenylhydantoin $の 3$ 週間投与後中止する と, 再び ep 系マウス個有の疗杽発作がおこくとも 6 日以後より出現してくる。

稿を゙終るとあたり彻指学，御鞍慥下さり，御校閲

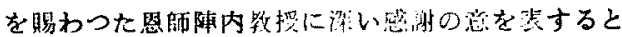

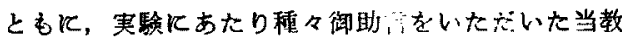
室の榑士に深謝する。

Neurol. , 15, 92, 1961.

13）宇野：岡山医学会雑誌，73，771，1961.

14）川上：用山医学会雑誌，71，7305，1959.

15) Tower, D. B. : Neurochemistry of Epilepsy, Charles C. Thomas. Publischer. 1960.

16) 西本, 沼本, 森：綜合医学，19，393，1962.

17）西本，䒜，摹波他：第 3 回 GABA.GABOB 及 び関運物啠研究会発站. 1962.

18) Noach, E. L., Woodbury, D. M. and Goodman, L. S. : J. Pharmacol. \& Exper. Ther., 122, 301, 1958.

19) Dill, W. A., Kazenko, A. Wolf, L. M. and Glazeko, A. J.: J. Pharmacol. \& Exper. Ther., $118,270,1956$.

20) Hine, C. H. and Kozelka, F. L.: J. Pharmacol. \& Exper. Ther., 72 276, 1941.

21) Dill, W.A., Kazenko, A., Wolf, L.M. and 
Glazeko, A. J. : Federation Proc., 15, 49, 1956.

22) Greengard, O. and Mc Ilwain, H.: Biochem. J., 61, 61, 1955.
23) Greengard, 0 . and Mc Ilwain, H.: J. Neurochem. , 1, 348, 1957.

\title{
Experimental Study on Inhibition of the ep-Mouse Convulsion
}

\author{
Part 1 Anti-convulsants and Their Effects on the ep-Mouse Convulsion \\ By
}

\section{Junzi Kasahara}

Department of Surgery and Neurosurgery, Okayama Univ. Med. School

(Director: Prof. D. Jinnai)

Various dosages of glutamic acid, asparagine, GABA ( $\gamma$-aminobutyric acid), GABOB $(\gamma$ amino- $\beta$-hydroxybutyric acid) and diphenylhydantoin each were given to the ep nouse once a day for 3 wesks and their effects on the convulsive seizure were compared.

1. Thre 3 week successive administration of various dosages, each if glutamic acid, asparagine, $\mathrm{GABA}$ and $\mathrm{GABOB}$, could not inhibit convulsive seizure in the ep moise.

2. In contrast, diphenylydantoin revealed to inhibit the convulsion: an absolute abolishment of the seizure was obtained a week, three days and 8 hours after the a:ministration of $40-60,80$ and $100 \mathrm{my} / \mathrm{kg} /$ day of diphenylhydantoin respectively.

3. The convulsive seizure in the ep mouse was found to recur within 6 days after the abstention of diphenylhydantoin administration. 